This is the author's version of a work that was submitted to / accepted for publication. To cite this article:

Hemming, P. J. (2011). Educating for religious citizenship: multiculturalism and national identity in an English multi-faith primary school. Transactions of the Institute of British Geographers 36(3), pp. 441-454. (10.1111/j.1475-5661.2011.00432.x)

\title{
Educating for religious citizenship: multiculturalism and national identity in an English multi-faith primary school
}

\author{
Peter J Hemming \\ Centre for Human Geography, Brunel University, Uxbridge, Middlesex UB8 3PH \\ email: peter.hemming@brunel.ac.uk
}

\begin{abstract}
Much attention has been paid to the introduction of Citizenship Education in 2002 as a curriculum subject for schools in England and Wales. However, schools have a much wider role in educating children for citizenship through the informal curriculum and everyday socio-spatial practices. This article draws attention to the issue of 'religious citizenship' as an important area of study for geographers, through a focus on a particular space: an English multi-faith community primary school. The model of religious citizenship that was provided and promoted by the school is considered, with reference to the way in which religious minorities were recognised and accommodated. Through this analysis, the significance of procedural liberalism is highlighted, particularly the way in which the concept of neutrality may inadvertently privilege certain groups over others. The multi-scalar nature of the issues in question are also shown through reference to particular constructions of the nation and national identity, along with the significance of everyday micro-spaces for the contestation and negotiation of religious citizenship.
\end{abstract}

Key words: Britain, religion, citizenship, education, multiculturalism, national identity 


\section{Introduction}

The 1998 Crick Report provided a blueprint for the establishment of Citizenship Education in England and Wales. This means that since 2002, all pupils of secondary school age (11-16) have been expected to participate in a curriculum designed around the three dimensions of 'political literacy', 'social and moral responsibility' and 'community involvement' (QCA Advisory Group on Citizenship 1998). The programme was developed in part as a response to concerns about an apparent lack of civic and political engagement, particularly among young people (Crick 2003). It also sought to address the perceived need for a stronger sense of national identity in the context of globalisation, migration and the increasing cultural diversity of schools and communities (Lawson and Scott 2002; Osler and Starkey 2006). Citizenship Education can therefore be understood as an attempt by the state to produce 'improved' citizens, through the adoption of predefined values and behaviours (Parry 2003; Ross 2002). Although the citizenship curriculum is not compulsory at primary school level (pupils aged 5-11), elements of it are nevertheless taught in many schools through nonstatutory Personal, Social, Health and Citizenship Education (PSHCE). ${ }^{1}$

The role of schools and education for the transmission of citizenship values (particularly of the neoliberal and cosmopolitan kind) has been an area of interest for scholars from a range of disciplines, including human geography (e.g. Matthews and Sidhu 2005; Mitchell 2003; Rawlins 2008). Many of these studies have emphasised the importance of the everyday practices and discourses that constitute a type of informal, non-curriculum-based citizenship education, conveyed through whole school ethos (Brown 2000). Following this line of enquiry, recent work in social and cultural geography has highlighted the significance of various school spaces for the shaping of young citizens (e.g. Gallagher 2005; Gordon et al. 2000; Hemming 2007). Although this body of work has focused on a range of issues, including health, discipline and identity, little attention has yet been paid to the issue of religion and its connection to citizenship in education spaces. One notable exception to this is Kong's (2005) work on Islamic schools in Singapore, where she shows how school practices can simultaneously contradict and complement state citizenship discourses on multiculturalism and modernity. However, there is a need for more geographical research on religion and citizenship education in more mainstream state school contexts. 
In this article, I explore the informal religious citizenship education that was being provided by a multi-faith community primary school in England. I begin the paper with two theoretical discussions, firstly about the nature of citizenship and secondly about multicultural citizenship. Building on these, I go on to outline the concept of religious citizenship, with particular reference to the contemporary British context. The remainder of the article is devoted to an examination of how these processes played out through everyday practices and discourses within the case study school context, from the perspective of teachers, pupils and parents associated with the institution. In doing this, I highlight the significance of religion to debates about multicultural citizenship and the construction of British national identity, thus making a case for geographers to pay more attention to religious citizenship as an important area of study across a range of spatial contexts.

\section{The nature of citizenship}

Marshall (1950 [1973]) originally defined citizenship in terms of civil/legal, political and social rights in the context of the nation state, including aspects such as freedom of speech, the right to vote and access to welfare. While this universal conception of national citizenship may have provided an appropriate framework in the past, forces of globalisation and increasing international mobility have created a changing context that requires more complex understandings of the relationship between citizen and polity. Joppke (1999)

highlights how post-war immigration has revealed the concept of citizenship to be much less inclusive than previous definitions, both through the demarcation and policing of state boundaries, but also through the potential of culture to exclude and privilege certain citizens over others. Through this lens, citizenship is not just about the position of an individual citizen in relation to a body of political authority, but also the extent of acceptance and belonging within a community of other citizens. The concept can therefore be understood as encompassing issues of social inequality and power differences, and possessing a social and cultural dimension, as well as a political dimension (Painter and Philo 1995; Turner 1993). 
New conceptions of citizenship have also moved away from the quite static and contractual language of rights and associated responsibilities, instead stressing its fluid character. A number of geographers have pointed to the contested nature of citizenship, and the ongoing power struggles for rights and inclusions that it necessarily entails (e.g. Ho 2006; McEwan 2000). Such understandings often imply a process of negotiation between the state on the one hand and the individual on the other, both in political and social/cultural terms. This is a relationship that Ong highlights through her concept of 'cultural citizenship', which she defines as:

the cultural practices and beliefs produced out of negotiating the often ambivalent and contested relations with the state and its hegemonic forms that establish the criteria of belonging within a national population and territory. $(1996,738)$

In this light, citizenship is thus viewed as a complex process rather than a fixed given, encompassing both a rights (political) and a belonging (social / cultural) aspect, and constituted through subjective and often quite contradictory practices and discourses (Ho 2006). Integral to definitions of citizenship as a contested process is the significance of mundane, habitual and everyday practices (Dickenson et al. 2008), in the context of intersecting and overlapping spaces and scales (see Massey 2004). The two concepts of 'governmentality' and 'prosaics' are useful here. Although one is couched in Foucauldian language and the other stems from the work of Bakhtin, both are concerned with making sense of the ways in which the state permeates the ordinary and unexceptional experiences of everyday life. As Painter argues:

governmentality draws attention to the construction of the objects of government, and to the logics, rationalities and technologies of rule, whereas prosaics highlights the unsystematic, the indeterminate and the unintended. $(2006,763)$

Together these approaches create space for both agents of the state and individual citizens themselves to intentionally or unintentionally reformulate and renegotiate citizenship processes through everyday practices and discourses. Citizenship is therefore revealed as inherently geographical, through the ways in which processes transcend the scalar 
boundaries of institution, locality, civil society, nation and globe (Dickenson et al. 2008; Mitchell 2003).

\section{Multicultural citizenship}

The concept of citizenship is frequently considered in relation to the ethnic and cultural profile of states, and it is in this context that Joppke (2007) identifies three dimensions to contemporary citizenship developments. The first dimension is 'status', and Joppke (2007) argues that one of the defining aspects of the post-war period has been the liberalisation of access to citizenship for ethnic and cultural minorities in western states. Specifically, he points to a changing emphasis away from jus sanguinis (law of the blood), where individuals gain national citizenship rights based on ethnic ancestry, towards the principle of jus soli (law of the soil), where individuals gain automatic citizenship in the country they were born in. One of the obvious consequences of this change has been the growth of more ethnically and culturally diverse populations, which has implications for the second 'rights' dimension of citizenship. Joppke (2007) maintains that these demographic transformations have led to a shift away from solidarity, in the form of social rights and welfare entitlements, towards diversity, in the form of procedural civil rights, particularly for minorities. These developments have included the establishment or strengthening of minority rights, often through policies of multiculturalism.

According to Kymlicka $(2007,80)$, multiculturalism pursues both the 'politics of identity' and the 'politics of interests', or to put this another way, through recognition of minority cultures on the one hand and accommodation of minority groups through the redistribution of power on the other. At the level of nation states, recognition might include publicly valuing the contributions of minority groups to world history, ensuring that members of the group are visible in media programming, or making particular efforts to avoid negative stereotyping. Accommodation and redistribution of power might include the revision of discriminatory institutional rules or practices such as dress codes and language requirements. Historically, where recognition for minority groups has finally been achieved, this has often been used as a springboard for the subsequent development of appropriate accommodations for these groups (Kymlicka 2007). However, Joppke (2007) argues 
that liberal states very rarely pursue explicit policies of active recognition and accommodation through the granting of group rights, because this would contradict the principle of neutrality, where the state maintains philosophical indifference to cultural variance. Instead, procedural liberalism views cultural difference as significant in the context of individual rights, such as respect for difference and the right of non-discrimination.

The liberal principle of neutrality is also relevant for Joppke's (2007) third and final dimension of citizenship: 'identity'. With the diversification of national populations, it is much more difficult for the liberal state to promote a particular form of unity and national identity, apart from universalistic values such as freedom, equality and tolerance, which are relevant across many western states and are not particular to any single nation (Joppke 2007). However, this situation does not detract from a certain amount of privilege enjoyed by ethnic majority populations over their immigrant minority co-habitants, through formal cultural arrangements such as official languages and public holidays (Joppke 1999). These aspects draw attention to the fact that the universalistic identity of liberal states is only one part of the story. A distinct and fixed national identity, drawing on the heritage of past times, is often present in the collective imagination of state members (Anderson 1983; Sharp 1996), even if cultures are in reality more likely to be heterogeneous, complex and in a constant state of flux (Chambers 1993). The result of this mismatch is a certain degree of national anxiety about the identity issue, often reflected in public discussion about how the nation should be represented, for example in school history and literature curricula (Isin and Wood 1999).

Such concerns over national identity often feed into wider debates about multiculturalism and the extent to which cultures can successfully co-exist, without the need for immigrants to 'integrate' into and adopt the cultural identity of the host society and population. In recent years, many scholars have noted a move away from multicultural policies in western states, in favour of integration, even if it is not always completely clear what immigrants are being asked to integrate into (e.g. Brubaker 2003; Joppke 2004; Mitchell 2004). This has led to a reaffirmation of the idea of national collective identity, but often articulated at the level of ethical and political values. Increasingly, immigrants are required to demonstrate not only their identification with host cultures but also their prescription to established norms and 
values, in order to be accepted as deserving of national citizenship (Fortier 2007; Mitchell 2004; Yuval-Davis 2006). This shift away from cultural customs and traditions, towards values and morals, has even been described as a new form of cultural racism and a new way of marking difference (Balibar 1991, cited in Fortier 2007, 109). It is in this context that religion and faith, rather than ethnicity and culture, come to the forefront of discussions about citizenship and multicultural citizenship.

\section{Religious citizenship}

Building on the last two discussions about the nature of citizenship and multicultural citizenship, in this section, I introduce the concept of religious citizenship, with particular reference to the contemporary British context. Human geographers have, in the past, identified a number of axes of difference (other than ethnicity and culture) through which processes of citizenship are played out, including, gender, sexuality, age and disability (e.g. Bell 1995; Chouinard 2004; Crooks et al. 2008; Gaskell 2008). My focus on religious citizenship reflects an increasing political and academic interest in religion as a significant factor for understanding individuals and society (e.g. Kong 2010). Religious citizenship relates to all three of Joppke's (2007) dimensions of citizenship: status, rights and identity (see earlier). It is about the role of religion in devising criteria for access to state or community membership, the political rights and responsibilities attributed to particular religious groups within that membership, and the religious aspects of collective social/ cultural identity that influence belonging. It is also about the everyday practices and discourses that contribute to the evolving dynamics of these three dimensions.

Although I have identified religious citizenship as a discrete aspect of citizenship, it cannot be understood in isolation from multicultural citizenship, and the negotiation of religious and cultural rights, belonging and acceptance within a particular national community. As Parekh (2000) highlights, culture and religion maintain a complex relationship with each other. While religion may influence beliefs and practices within a particular culture, that same culture will shape the interpretation and enactment of religion, and the role that it plays in society. However, this does not mean that the two concepts are one and the same thing. Religious practices and beliefs may be pursued for social or cultural reasons, in 
isolation from their associated religious meanings (Parekh 2000). Similarly, religious affiliations may take on greater significance than cultural identifications, as a number of scholars have illustrated in relation to religious minorities in Britain (e.g. Raj 2000; Valentine and Sporton 2009). The concept of religious citizenship is therefore distinct from Ong's (1996) cultural citizenship, but the two are nevertheless closely related, as will become apparent later in the article.

The above point is particularly pertinent in the context of increasing religious diversity in Britain. In the 2001 Census, at least 5 per cent of the population of England and Wales defined themselves as members of a minority religious group: Muslim, Sikh, Hindu or Jewish (National Statistics website 2001). Not all of these religious groups are associated with just one culture or ethnicity. For example, Muslims originate from six distinct linguistic and geographical zones, each with different histories, cultures and relationships with the west (Lewis 2007). However, many of the issues and developments outlined in the earlier section on multicultural citizenship are also relevant in this multi-faith context. Scholars have argued that rights and accommodations for religious minorities in Britain are negotiated within a context of shifting policy discourse away from multiculturalism and towards integration (Back et al. 2002). It is suggested that concerns about the ability of religious minorities to integrate into 'British culture' are also articulated through selective 'othering' processes and new cultural racisms, directed at particular groups such as Muslims (Modood 2005). Furthermore, these processes are all said to be taking place against a backdrop of continued uncertainty about what it means to be British (Gamble 2003; Turner 2006).

Although politicians in the present era of diversity have attempted to promote particular constructions of 'Britishness', these have again drawn on universal liberal values, rather than religious concepts and ideas, even when presented in opposition to Muslim fundamentalism. ${ }^{2}$ Callum Brown (2010) argues that the Christian culture that constituted the core moral and religious identity of the nation before 1960 is no longer present in contemporary Britain. With reference to the changing cultural discourses through which citizens construct their identities, rather than merely the issue of church decline, Brown (2010) claims that Britain can no longer be described as a Christian country. Although there 
is much evidence to support the proposition that the influence of Christianity is indeed declining significantly in Britain (e.g. Voas and Crockett 2005), certain scholars have pointed to traces of Christian heritage that continue to influence the cultural fabric of the nation. For example, Davie (2000) points to continued support for the existence of state churches in Britain and other European countries, particularly their involvement in education, welfare, national celebrations and rites of passage. These observations suggest that Christianity could still maintain a place within imagined popular constructions of British national identity, even in the context of a secular liberal state. Religious citizenship in Britain is therefore negotiated within these particular national identity discourses, as will become apparent in the remainder of this article.

\section{Methodology}

The material presented in this paper is taken from a wider mixed-method qualitative study on the role of religion and spirituality in the spaces of the primary school (see Hemming 2009). In this article, I focus on the way in which everyday practices and discourses played a role in the informal (religious) citizenship education provided by one of the case study schools that made up the sample for that research. The school in question was a community primary school located in a multi-faith urban area in the north of England. For the purposes of this article, I will refer to the school under the pseudonym of Rainbow Hill. Rainbow Hill had just under 350 pupils registered (aged 5-11) at the time of the study and a multi-faith pupil intake, reflecting the surrounding community. Like all English community schools, there were opportunities for religion to play a role in school life through Religious Education (RE) and whole-school assemblies, although it was not particularly prominent at Rainbow Hill (see Hemming 2009). The research focused mainly on one Year 5 / 6 class (9-11-yearolds), which included approximately 20 per cent non-white Muslim or Sikh, 40 per cent black or mixed race Christian, 30 per cent white Christian and 10 per cent children with no religion (mostly white). Although the wider study involved a range of qualitative methods, including participant observation and child-centred creative tasks, I will focus primarily on the semi-structured interviews for the purpose of this article. 
The interviews included 3 staff interviews, 10 parent interviews and a number of paired interviews with children (11 pairs and one group of 3). The staff interviews were conducted after school and lasted for about an hour. Although teachers may well have attempted to present school practices in a particularly positive light, my own observations (over a period of 10 weeks) did not significantly contradict the claims made in quotes used in this article. Parent interviews were conducted at home or at school for around half an hour, and mainly involved just one parent, except for two cases, where both parents were involved. Paired interviews, where children chose their own partner, were conducted in order to address some of the ethical issues inherent in child and youth research, particularly uneven power differentials (see Mayall 2000). They took place during school hours, in private spaces away from staff, and lasted about half an hour. In all cases, participants were asked their religious affiliation, and their answers form the basis of the labels used in this article. Pseudonyms are used here to protect the identity of interviewees.

\section{Religious recognition: marking and celebrating festivals}

As is apparent in the previous section on religious citizenship, multicultural citizenship is often referred to in rather grand terms, with reference to macro-processes at the level of state discourse and policy. However, the ways in which these processes operate at an everyday level involve practices of a much more ordinary and mundane nature (Dickenson et al. 2008). Kymlicka's (2007) distinction between 'recognition' and 'accommodation' of minorities, outlined earlier in the article, is a useful starting point for making sense of multicultural citizenship at a variety of scales, from national policies to local and institutional practices. For this reason, I use it as an initial framework for analysing religious citizenship in the context of the multi-faith case study school in question. Specifically, I focus on the way in which the school catered for the needs of its faith minorities through religious recognition and accommodation, and the implications of these practices and associated responses, for the type of religious citizenship promoted in school. I begin with the issue of religious recognition.

At Rainbow Hill, there were a number of ordinary contexts and practices through which minority faiths and religious diversity could be recognised and acknowledged. One of these 
times was during RE lessons, where the curriculum covered a number of religions alongside Christianity. Similarly, one of the other multi-faith features of everyday life in school was the multitude of religious festivals marked at different times of the year. Nesbitt (2004) reports that multi-faith schools increasingly celebrate a range of religious festivals such as Diwali and Eid, although she argues they may create multiple meanings in the way that they either perpetuate or modify traditions of celebration. The significance of non-Christian festivals was particularly well covered in assemblies and informal RE input in the study class I observed. Such occasions were a common theme across many of the interviews and provide a useful case study into some of the citizenship issues under consideration.

INTERVIEWER:

Festivals - you said Harvest Festival and Christmas. Do you celebrate any other festivals? CLASS TEACHER (female agnostic):

Yeah we celebrate Diwali, not always as a whole school but certainly at the time of Diwali, there might be, you know, lower down the school they might be doing some sort of art work or the, I can't think what they're called now.

INTERVIEWER:

Oh the lamps?

CLASS TEACHER:

Yeah and at the end of Ramadan, we've had Eid parties in the past. We have a Christmas celebration and an Easter, like an Easter assembly. I mean, there are sometimes other things that come in as well. We might have a, one of the ethos statements is like stories from other faiths and other festivals and things, so different things come up, but l'd say that they're the main ...

INTERVIEWER:

So I mean is that generally decided on the basis of what would be meaningful for the children? So I mean, you do kind of festivals from the school community, so they wouldn't be celebrating something that's not part of the school community?

CLASS TEACHER:

Yeah. No, for example, during Ramadan, some of the children have brought in their prayer mats and showed the other children those and sort of talked about why they pray and why they're fasting. Not a big special assembly, but part of a normal week, as that's important for the children to explain why things might look a bit different in school. In the interviews, 
children also reflected on how they had learnt about religions such as Islam, Judaism and Christianity in past RE lessons and also celebrated various festivals in different ways.

\section{INTERVIEWER:}

Ok do you ever celebrate other religious festivals like Diwali?

MARY and KAVITA:

No.

KAVITA (Asian Sikh girl):

Yeah.

MARY (Black Christian girl):

Diwali, we do celebrate Diwali sometimes.

INTERVIEWER:

But not many others?

KAVITA:

No, but Diwali we just did once I think, because when these, yeah in my country, from my religion these people came who dressed up like my God, like we do, these two people they told us about the story, how they make Diwali, what they do in the streets and all that.

Although the above quotes indicate the acknowledgement of a number of non-Christian festivals in school, they also point to the limits of this approach at Rainbow Hill. Diwali and Eid were marked and discussed, but were not celebrated to the same extent as the Christian festivals. The way in which the Christian festivals tended to enjoy greater recognition over those from other faiths was also highlighted by some of the parents. For example, Shabina, a Muslim mother, felt that it would be good for the school to hold a larger party for Eid, in the same way as they did for Christmas.

SHABINA (Asian Muslim mother):

[... ] In the [nursery school] they do, they'd have like, if it's Eid, they'd have like an Eid party, like with Christmas they do, they have a party. But l've noticed with [Rainbow Hill] they don't actually, as far as I know, they don't have an Eid party or a Diwali party or anything, I think they learn about it but they don't actually have a party.

INTERVIEWER:

Yeah they learn about it but they don't tend to have a celebration. SHABINA: 
Yeah they don't, I've noticed that they don't do that. I mean it was when I used to go to the [nursery school], they did have a party there. They all used to bring a dish each and they did, but I've noticed at the school, I don't know if it's the same at every school, but that's what I've noticed that they don't have any. It would be nice if they did.

The Head Teacher insisted that the lack of whole school celebrations for these non-Christian festivals was down to lack of organisation, rather than deliberate omissions, but Christmas was a much bigger event and it seemed unlikely that this would have been forgotten due to lack of organisation. The Christmas celebrations at Rainbow Hill were high in profile and Christmas trees and decorations were present in some of the classrooms. At the start of one of the nativity plays, the Head Teacher made a point of saying that the school would not be cancelling Christmas as the media had reported other schools had done that year. Despite the desire to value diversity, Christianity still took precedence to a certain extent.

\footnotetext{
INTERVIEWER:

I know this sounds kind of an odd question really, because there isn't much religion in school, but the extent to which there is, would you say that Christianity still has, as the school is kind of not really Christian, would you say that Christianity still has a bit of a kind of top place above the others in some way? CLASS TEACHER (Female Christian):

Yes I mean it would do in the sense that we celebrate the two major festivals, throughout the school in some way, so I suppose it has, and most of the teaching staff are White and with Christianity in their backgrounds probably somewhere, so it is perhaps the default level for school isn't it?

INTERVIEWER:

Yeah.
}

Many of the children also discussed the merits of celebrating minority religious festivals in school during the paired interviews. While some were in favour of doing so in order to experience what their friends participated in, others felt that it was more appropriate for children from minority religions to celebrate them at home because the festivals were more meaningful to those individuals. 
INTERVIEWER:

Ok. Do you ever celebrate say Eid or things like that in school?

BILLY (White Christian boy):

Not in school, they do it outside school.

$[\ldots]$

INTERVIEWER:

Do you think that you should, that it would be nice to celebrate Eid or Diwali in school, or are you not bothered?

JOHN (White boy, no religion):

They told us to be, but it's boring a little.

INTERVIEWER:

It gets a bit boring. What do you think Billy?

BILLY:

Well school?

INTERVIEWER:

Yeah 'cos you celebrate Christmas, and you do harvest festival and Easter, so do you think you should do Eid and Diwali and things like that from other religions as well, or not?

BILLY:

I think for the people who are celebrating Eid, they should just do it for them.

INTERVIEWER:

Ok.

BILLY:

Because the others, other people don't celebrate Eid.

What seemed to be emerging from the interview narratives was the idea of Christianity as the default religion at Rainbow Hill, even if just in a cultural sense. Christianity was not something that was overtly discussed or referred to by many of the research participants, but it acted as an often unspoken yardstick against which decisions about religious recognitions were made. Major Christian festivals were the non-negotiable aspects of school life, and other religious occasions would only be celebrated if time and resources allowed. In many ways, this finding parallels some of the academic arguments about whiteness, which identify a tendency to construct whiteness as an unmarked and neutral ethnicity against which all other ethnicities should be understood and measured (e.g. 
Frankenberg 1993). Christian festivals, such as Christmas nativities, were a taken-forgranted part of school life, and did not generate a great deal of discussion on the part of many interviewees.

This acceptance of Christianity as the default religion in school was, however, not always silent in the interview transcripts. Some of the parents identified Christianity in a much more overt way, drawing on constructions of national identity in order to do so. The identification of England/Britain as a 'Christian country' was used as a way of expressing concerns about the need to achieve the right balance in the recognition and accommodation of religious minorities. For these parents, such as Sarah below, Christian festivals were an important part of the nation's cultural heritage and it was right that they should take primacy over other religious celebrations. Interestingly, the discourse of England/Britain as a Christian country was also reflected by some of the non-Christian interviewees, who accepted this as a reason why Christian festivals would take precedence over those from their own religion.

INTERVIEWER:

You talked about when they looked at different festivals. Actually, I mean they do have a big kind of celebration at Christmas as you know, and Easter. At Diwali and Eid, generally, classes might talk about those festivals in the class, but they wouldn't have quite such a big, kind of school-wide festival. I mean do you think that's the right balance?

SARAH (Black Christian Mormon mother):

I do, simply because this is England and it's a Christian country.

INTERVIEWER:

And the school needs to reflect that?

SARAH:

And I think that you can't take that out of the school completely. I think that it does need to have a bigger kind of celebration than the other religions, because, and that's what I always say to people that say, oh well it shouldn't have any place in there it all, it's like 'this is England!' If I went to another country to live for a while, I would expect them to big up their beliefs at that particular time, and it'd just be you know, the Christian faith would probably just be mentioned in passing. So because we live in England, and because it's a Christian country, I think that yes it's right, in my opinion. 
This finding supports Joppke's (1999) argument that, although the liberal state maintains an officially neutral position regarding religious affiliations, majority populations still tend to enjoy a certain amount of privilege over minorities because of formal cultural and religious arrangements. Although some of the Christian pupils in the class may not have been particularly religious, and some of the white pupils had no religion, these groups benefited from the prominence of Christian festivals in a cultural sense, whereas pupils from a range of cultures who actively followed Christianity, benefited from the arrangements in a religious sense. Religious citizenship, as well as cultural citizenship, was therefore influencing the parameters of belonging that religious minorities experienced and negotiated. Furthermore, local and national scales of religious citizenship were linked through the employment of constructions of British national identity and culture that emphasised its Christian nature. The importance of religion for understanding the informal citizenship education promoted in Rainbow Hill was further revealed through the way in which the school accommodated its religious minorities, as is outlined in the next section.

\section{Religious accommodation: granting minority rights}

In addition to acknowledging different religions in school, Rainbow Hill also catered for and accommodated particular religious needs. Smith (2005) found that lunchtimes in school can be a time when difference is reinforced, due to religious food requirements, and Nesbitt (2004) has highlighted the significance of food for the negotiation of children's religious identities. In my research, some of the children only ate Halal meat or were vegetarians due to their religion and this was catered for through the school dinner service. Other religious requirements included dress needs, where for example, Sikh children were permitted to wear religious bangles and many of the Muslim girls wore headscarves to school. An attempt was also made to cater for prayer needs, for example through allocating the school library as a Muslim prayer space during Ramadan.

CLASS TEACHER (Female Agnostic):

Most children sort of accept that we've got children from all over, so at certain times, there might be children fasting, and you know, we make allowances for that. But I remember, you 
know, we've been doing food things and it's happened to be when children are fasting and you know, they just haven't been able to taste things. But I mean, you try and work round that if you can, but you know, I don't sort of change the curriculum round to sort of fit in with children who are fasting, but then that's their choice. And I mean, I know a parent last year who came and said oh her daughter had said that l'd been really kind and kept asking her if she was alright when she was fasting. So you know, we try to be caring in that respect. The library is available for children to pray as well, I don't know if you might have seen some of the Muslim children coming up as well [...]. Some Muslim children have come up to pray, and we have done that at the old school as well, so you know it's important.

Another aspect of religious needs involved withdrawal requests. Parents had the right to withdraw their children from assemblies, RE lessons and Sex and Relationships Education (see Epstein and Johnson 1998), and such requests were always respected, although they were generally quite rare. Children from minority religions would take the day off school on festivals such as Eid and this was accepted as a legitimate reason for absence. Rainbow Hill therefore tried to take an open and accommodating approach to these needs in order to demonstrate respect for religious difference. Many of the parents expressed their satisfaction with the school's provision for these requirements.

\section{INTERVIEWER:}

Do you feel that the school caters for your religious needs, whether that be prayer needs, or food needs, or dress needs?

MONA (Asian Muslim mother):

Yes, yes. Because we are Muslims and when my child, I mean we are not supposed to eat pork and we are supposed to have Halal meats and once we've mentioned that, they've got provision for that.

Again, this provision for religious minorities within the community primary school context only went so far, reflecting the argument that a certain amount of incompatibility between liberally influenced education and values of particular religious communities will always exist (Archard 2003; Kymlicka 2003). As mentioned by the class teacher in the above quote, the curriculum was not changed in order to accommodate fasting requirements. Likewise, staff explained that while they tried to be respectful of difference when it came to religious 
jewellery and Physical Education, legal health and safety requirements would always need to take priority in such situations. Children and parents also highlighted similar limitations to religious accommodations in the interviews. Interestingly, these included the religious requirements of minority Christian families who complained about the lack of prayer space and respect for the Friday Sabbath, as well as Muslim children who mentioned the lack of choice they experienced on restricted school dinners, or problems with bringing in prayer mats to school.

INTERVIEWER:

When you're praying in the library, how do you feel when you are doing that?

VANESSA (Black Muslim girl):

We feel normal, we just pray like normal.

ZAM (Black Muslim girl):

And there's sometimes, we're supposed to bring our mats, but sometimes we don't have those big bags to bring our mats so we bring those [pillowslips] and they don't [stay clean], 'cos everyone sits on it.

VANESSA and ZAM:

(laughs)

INTERVIEWER:

Ok, oh so everyone sits on the bag?

ZAM:

Yeah.

VANESSA:

Yeah and sometimes so we're worried that it might not be.

ZAM:

[Clean]

VANESSA:

[...] They might, so sometimes we're worried that it might not be clean. Some people sit on it, maybe they step on it.

INTERVIEWER:

Oh.

VANESSA:

And in our prayer mat, it's supposed to be clean. 
HANNA (Black Pentecostal mother):

And the other thing, I don't know it was one day at school. There are certain times when they are supposed to go and pray, but being children, I don't think they're really following it. INTERVIEWER:

So maybe the school could encourage them to do that?

HANNA:

Yeah, 'cos Muslims they do go and pray.

INTERVIEWER:

Yeah during Ramadan they go to the library.

GAMBA (Black Pentecostal father):

During Ramadan yeah, during Ramadan.

HANNA:

But with my children, yeah, with my children, I don't think they, they do it. 'Cos it's one of them is that each and every, after every three hours, you should go and pray from 6, 9, 12, 3, 5 of which I don't think the children manage to do it. If myself I find it really difficult to do it at work.

These findings point to the significance of procedural liberalism, and its principles of respect and neutrality, for the granting of rights and provisions for minority religious needs in Rainbow Hill (Joppke 2007). In comparison to religious festivals recognition, the discourse of Britain as a Christian country was not quite as strong, although some of the limitations to special provisions were nevertheless based on legal and cultural arrangements developed within a western Christian societal context. These included the Monday-Friday working week, curriculum practices and health and safety legislation, which again resulted in a certain privileging of some groups over others. However, some of the responses to these arrangements were indicative of the role of religion in citizenship processes in rather different ways. Involving both parents and children, these examples underlined the contested nature of religious citizenship, and the way it can be understood as a fluid and evolving process, rather than a fixed set of rights and responsibilities. They also involved the everyday practices and discourses that are so essential for a full understanding of citizenship. 
The first example relates to the quite creative ways that children negotiated situations where their religious needs were not catered for in school. This was demonstrated most clearly through the creation of their own provisions for prayer. During one of the paired interviews, William told me that he had heard other children praying in the toilets when he had been in there. At first I approached this claim with scepticism, but scanning the other interview transcripts, I read a small reference to praying in toilets that I had not noticed during the interview itself. I spoke to the girls in question when I next saw them and they had indeed been praying in the toilets. Nicole, a Pentecostal Christian and Aisha, a Muslim, had both been using the toilets as private spaces in order to satisfy their daily prayer requirements. Similarly, Muslim pupils also constructed prayer provisions using mental techniques. Many of them told me they often changed the words of the Christian prayers so that they were appropriate for their own religion, or prayed to Allah in their heads. These practices revealed the ways in which children used their religious agency to negotiate their own religious citizenship through the everyday informal spaces in and around school (see also Hemming and Madge forthcoming).

INTERVIEWER:

So you know when you had that assembly on Friday and that group came in. So when they said at the end, you can pray if you want to, did you not pray then?

AISHA (Asian Muslim girl):

I did, but I didn't say Jesus, because he's not my God.

INTERVIEWER:

So what did you say instead?

AISHA:

I said Allah.

INTERVIEWER:

So you kind of changed the prayer so that it was ok for your religion?

AISHA:

Yeah.

These informal techniques of prayer are also linked to the second example. This relates to the attitudes of parents to some of the practices that pupils from non-western Christian backgrounds engaged with, in order to provide for their own religious needs. Previous 
research has shown that Christian parents have often expressed unhappiness about material on other religions undervaluing their 'cultural heritage' through inclusion in multifaith assemblies (McCreery 1993), and the assembly hall was also an arena for tensions in my research. Jane recalled a time when she had attended an assembly and Muslim pupils had reportedly disrespected the Christian worship that took place. She explicitly drew on the binary of 'us' and 'them' to express the view that these particular children had been ignorant towards British (Christian) culture. Jane's comments were indicative of a feeling that the tolerance and respect extended to minority religions in school were not always reciprocated, in a situation where taking part in Christian prayer may well have been inconsistent with Muslim children's religious needs.

JANE (White Christian mum):

I think if it got too religious, as in every assembly we had to bow our heads and pray, it wouldn't always go down very well with other cultures, other backgrounds, religious cultures, to be quite frank with you.

INTERVIEWER:

Right.

JANE:

And l've seen it happen, on the odd time we've had the vicar come in, you know from [the local church]. I think she came once while you were here.

INTERVIEWER:

Yeah she did yeah.

JANE:

I forgot her name even, but when that lady came in, the vicar stood there, and I think she said something about praying and bowing your head.

INTERVIEWER:

Yeah.

JANE:

Well, I'm not slagging any group off, but a lot of the Muslim children wouldn't bow their head, but yet I feel that just my daughter for example, if we had to do something, or get down on our knees and pray for them, she would do that. I know she would, but that to me was quite ignorant towards our culture. 
Such statements support the argument that citizenship and belonging are increasingly being negotiated through ethical values, rather than customs and traditions, making religion an even more significant marker of difference (Fortier 2007; Mitchell 2004; Yuval-Davis 2006). Practices that may have been important for children's individual religious identities were interpreted as failures to adopt accepted norms of tolerance and respect towards others. Such views link to wider national discourses that mark particular religions, especially Islam, as ethically inconsistent with British norms and values. These discourses draw on new cultural racisms (or perhaps this should be religious racisms) and processes of selective 'othering' in order to set the criteria for cultural and religious belonging (see Modood 2005). These findings again reveal religious citizenship as a multi-scalar process through the way that teacher, pupil and parent practices and discourses at an institutional level interconnect with wider conceptions of religious citizenship at the scale of the nation. Central to this understanding of religious citizenship is the significance of the everyday contestations and negotiations that underline its fluid and evolving nature.

\section{Conclusion}

Over the last decade, much attention has been paid to the introduction of Citizenship Education classes in England, but there has been much less interest in the more informal education in citizenship that schools offer outside of the formal curriculum. In this article, I have critically examined the religious citizenship that one particular English multi-faith community primary school (Rainbow Hill) was implicitly promoting as part of this process of informal citizenship education. I have defined the term 'religious citizenship' as the role of religion, and its associated practices and discourses, in devising criteria for access to state or community membership, the political rights and responsibilities attributed to particular religious groups within that membership, and the religious aspects of collective social and cultural identity that influence belonging. In the context of this study, I have considered only the 'rights' and the 'identity' dimensions of religious citizenship in the analysis (drawing on Joppke's (2007) conceptualisation), because school membership at Rainbow Hill, or the 'status' of pupils, was already determined through admissions procedures prior to the fieldwork period. However, the role of religious citizenship in such admissions decisions, particularly in the context of faith schools, is an important area for further geographical 
inquiry.

Rainbow Hill made many attempts both to acknowledge different faiths, for example through celebrating and marking a diverse range of religious festivals, and to accommodate religious needs, including food, dress and prayer needs. Procedural liberalism and the principle of neutrality was the guiding light for these arrangements, but as Joppke (1999) points out, such decision-making often results in the unintended privileging of majority populations, through formal cultural arrangements. In the case of Rainbow Hill, certain pupils were privileged over others because of the limitations to these recognitions and accommodations: the prominence of Christian festivals and the effect of legal requirements developed in a western Christian context. Christianity acted as an implicit default religion in school, even if, for some, this was understood in a cultural rather than a religious way. It therefore inhabited a similar position to whiteness in the context of ethnic difference, denoting an often invisible but privileged status. However, this state of affairs could not have been adequately explained through theories of multicultural citizenship alone. Religious identity added another layer of stratification, distinct from ethnic and cultural difference, influencing who was privileged and who was not. This had the effect of differentiating pupils who might be described as 'white', 'black' or 'Asian' by their religious affiliation, rather than just their culture or ethnicity. It was religious citizenship, rather than cultural citizenship, that structured these particular processes at Rainbow Hill.

The multi-scalar and intensely geographical nature of religious citizenship in Rainbow Hill was highlighted in two distinct ways. The first of these involved the employment of particular constructions of the nation, which worked to privilege the Christian cultural and religious majority. The idea of Britain as a Christian country was used by some interviewees to justify why Christian festivals should continue to enjoy increased prominence over other religious festivals. Similarly, the construction of British national values as encompassing respect, tolerance and inclusion was drawn upon as a means to express disapproval of the actions of particular religious minorities, who were portrayed as lacking in those values. Both of these findings point to the significance of religion for understanding national identity, whether that be through the increasing tendency to negotiate state citizenship and belonging at the level of ethics and values (Fortier 2007; Mitchell 2004; Yuval-Davis 2006), 
or through the complex and evolving ways of defining national culture. Although Davie (2000) suggests that Christianity still maintains a presence in the national consciousness of western states through its role as a public utility, I would also argue that Christianity is of increasing importance as a social label and way of distinguishing religious difference in such contexts. As Day (2009) has shown, when research participants choose the label 'Christian' they are much more likely to be referring to their social and ethnic affiliations and identities than an active religious position. For some people, Britain may well be understood as a Christian country in order to differentiate its identity from an Islamic or Jewish country.

The second way in which religious citizenship was revealed as operating within intersecting and overlapping spaces was through the significance of mundane and everyday environments within Rainbow Hill. The practices discussed in the analysis, such as celebrations and prayer, all took place at the micro-scale of the classroom, assembly hall, library and bathroom, yet connected to wider processes at both an institutional and a national level. The discourses expressed by parents and teachers about arrangements in school were embedded in the institution or local community, but could not be understood without reference to wider discourses circulating at different scales. This focus on ordinary, everyday practices and discourses also underlined the fluid and contested notion of religious citizenship. Children at Rainbow Hill created and negotiated their own religious provisions and, compared with teachers, parents often expressed alternative views about the religious recognitions and accommodations that pupils from minority faiths experienced. Such findings highlight the practical and policy functions that research on religious citizenship can provide. Awareness of some of the issues that religious minorities face in school, and some of the views that parents hold, can be a first step towards developing more inclusive models of informal citizenship education. Similar research in other contexts, such as the home, the hospital and the street, could also have a real impact on policy and practice, in addition to deepening theoretical understandings of the role of religion and citizenship processes in contemporary society. Religious citizenship is therefore a concept that deserves much more attention in the geography discipline. 


\section{Acknowledgements}

I would like to thank the ESRC and University of Leeds for the opportunity to undertake the $\mathrm{PhD}$ on which this research is based. Thanks also to Gill Valentine, Sarah Irwin and the anonymous referees for their suggestions and advice.

Notes

1. See QCA (2009).

2. For example, Gordon Brown's (2007) speech.

\section{References}

Anderson B 1983 Imagined communities Verso, London

Archard D 2003 Citizenship education and multiculturalism in Lockyer A, Crick B and Annette J eds Education for democratic citizenship: issues of theory and practice Ashgate, Aldershot 89-102

Back L, Keith M, Khan A, Shukra K and Solomos J 2002 New Labour's white heart: politics, multiculturalism and the return of assimilation Political Quarterly 73 445-54

Bell D 1995 Pleasure and danger: the paradoxical spaces of sexual citizenship Political Geography 14 139-53

Brown C G 2010 The death of Christian Britain 2nd edn Routledge, London

Brown D 2000 Implementing citizenship education in a primary school in Osler A ed Citizenship and democracy in schools: diversity, identity, equality Trentham, Stoke-on-Trent $113-24$ 
Brown G 2007 Speech: Britishness

(http://www.guardian.co.uk/politics/2007/feb/27/immigrationpolicy.race) Accessed 19 June 2009

Brubaker R 2003 The return of assimilation? Changing perspectives on immigration and its sequels in France, Germany and the United States in Joppke C and Morawska E eds Towards assimilation and citizenship: immigrants in liberal nation-states Palgrave Macmillan, Basingstoke 39-58

Chambers I 1993 Narratives of nationalism: being 'British' in Carter E, Donald J and Squires J eds Space and place: theories of identity and location Lawrence and Wishart, London 14564

Chouinard V 2004 Making feminist sense of the state and citizenship in Staeheli L A, Kofman E and Peake L eds Mapping women, making politics: feminist perspectives on political geography Routledge, Abingdon 227-44

Crick B 2003 The English citizenship order 1999: context, content and presuppositions in Lockyer A, Crick B and Annette J eds Education for democratic citizenship: issues of theory and practice Ashgate, Aldershot 15-29

Crooks V A, Dorn M L and Wilton R D 2008 Emerging scholarship in the geographies of disability Health and Place 14 883-8

Davie G 2000 Religion in modern Europe: a memory mutates Oxford University Press, Oxford Day A 2009 Researching belief without asking religious questions Fieldwork in Religion 4 89106

Dickenson J, Andrucki M J, Rawlins E, Hale D and Cook V 2008 Introduction: Geographies of everyday citizenship ACME 7 100-12 
Epstein D and Johnson R 1998 Schooling sexualities Open University Press, Buckingham

Fortier A 2007 Too close for comfort: loving thy neighbour and the management of multicultural intimacies Environment and Planning D: Society and Space 25 104-19

Frankenberg R 1993 White women, race matters: the social construction of whiteness Routledge, London

Gallagher M 2005 Producing the schooled subject: techniques of power in a primary school Unpublished PhD thesis, University of Edinburgh

Gamble A 2003 Between Britain and America Palgrave, London

Gaskell C 2008 'But they just don't respect us': young people's experiences of (dis)respected citizenship and the New Labour respect agenda Children's Geographies 6 223-38

Gordon T, Holland J and Lahelma E 2000 Making spaces: citizenship and difference in schools Macmillan, Basingstoke

Hemming P J 2007 Renegotiating the primary school: children's emotional geographies of sport, exercise and active play Children's Geographies 5 353-71

Hemming P J 2009 Religion and spirituality in the spaces of the primary school: social and political explorations Unpublished PhD thesis University of Leeds

Hemming P J and Madge N forthcoming Researching children, youth and religion: identity, complexity and agency Childhood

Ho E 2006 Negotiating belonging and perceptions of citizenship in a transnational world: Singapore, a cosmopolis? Social and Cultural Geography 7 385-401

Isin E F and Wood P K 1999 Citizenship and identity Sage, London 
Joppke C 1999 How immigration is changing citizenship: a comparative view Ethnic and Racial Studies 22 629-52

Joppke C 2004 The retreat of multiculturalism in the liberal state: theory and policy British Journal of Sociology 55 237-57

Joppke C 2007 Transformation of citizenship: status, rights, identity Citizenship Studies 11 37-48

Kong L 2005 Religious schools: for spirit, (f)or nation Environment and Planning D: Society and Space 23 615-31

Kong L 2010 Global shifts, theoretical shifts: changing geographies of religion Progress in Human Geography 34 755-76

Kymlicka W 2003 Two dilemmas of citizenship education in pluralist societies in Lockyer A, Crick B and Annette J eds Education for democratic citizenship: issues of theory and practice Ashgate, Aldershot 47-63

Kymlicka W 2007 Multicultural odysseys: navigating the new international politics of diversity Oxford University Press, Oxford

Lawson H and Scott D 2002 Introduction in Scott D and Lawson H eds Citizenship education and the curriculum Ablex London 1-6

Lewis P 2007 Young, British and Muslim Continuum, London Marshall T H 1950 [1973] Class, citizenship and social development Greenwood, Westport CT 
Matthews J and Sidhu R 2005 Desperately seeing the global subject: international education, citizenship and cosmopolitanism Globalization, Societies and Education 3 49-66

Mayall B 2000 Conversations with children: working with generational issues in Christensen P and James A eds Research with children: perspectives and practices RoutledgeFalmer, London 120-35

McCreery E 1993 Worship in the primary school David Fulton, London

McEwan C 2000 Engendering citizenship: gendered spaces of democracy in South Africa Political Geography 19 627-51

Mitchell K 2003 Educating the national citizen in neoliberal times: from the multicultural self to the strategic cosmopolitan Transactions of the Institute of British Geographers NS 28 387-403

Mitchell K 2004 Geographies of identity: multiculturalism unplugged Progress in Human Geography 28 641-51

Modood T 2005 Multicultural politics: racism, ethnicity and Muslim in Britain Edinburgh University Press, Edinburgh

National Statistics Website 2001 Census 2001

(http://www.statistics.gov.uk/census2001/census2001.asp) Accessed 2

September 2009

Nesbitt E 2004 Intercultural education: ethnographic and religious approaches Sussex Academic Press, Brighton

Ong A 1996 Cultural citizenship as subject-making: immigrants negotiate racial and cultural boundaries in the United States Current Anthropology 37 737-62 
Osler A and Starkey H 2006 Education for democratic citizenship: a review of research, policy and practice 1995-2005 Research Papers in Education 21 433-66

Painter J 2006 Prosaic geographies of stateness Political Geography 25 752-74

Painter J and Philo C 1995 Spaces of citizenship: an introduction Political Geography 14 10720

Parekh B 2000 Rethinking multiculturalism: cultural diversity and political theory Palgrave, Basingstoke

Parry G 2003 Citizenship education: reproductive and remedial in Lockyer A, Crick B and Annette J eds Education for democratic citizenship: issues of theory and practice Ashgate, Aldershot 30-46

QCA 2009 Schemes of work website (http://www.standards.dfes.gov.uk/schemes2/ks12citizenship/?view=get) Accessed 2 September 2009

QCA Advisory Group on Citizenship 1998 Education for citizenship and the teaching of democracy in schools: final report of the Advisory Group on Citizenship Qualifications and Curriculum Authority, London

Raj D S 2000 'Who the hell do you think you are?' Promoting religious identity among young Hindus in Britain Ethnic and Racial Studies 23 535-58

Rawlins E 2008 Citizenship, health education and the UK obesity 'crisis' ACME 7 135-51

Ross A 2002 Citizenship education and curriculum theory in Scott D and Lawson H eds Citizenship education and the curriculum Ablex London 45-62 
Sharp J P 1996 Gendering nationhood: a feminist engagement with national identity in Duncan N ed Bodyspace: destabilizing geographies of gender and sexuality Routledge, London 97-108

Smith G 2005 Children's perspectives on believing and belonging National Children's Bureau for the Joseph Rowntree Foundation, London

Turner B S 1993 Contemporary problems in the theory of citizenship in Turner B S ed Citizenship and social theory Sage, London 1-18

Turner B S 2006 Citizenship and the crisis of multiculturalism Citizenship Studies 10 607-18

Valentine G and Sporton D 2009 'How other people see you, it's like nothing that's inside': the impact of processes of disidentification and disavowel on young people's subjectivities Sociology $43735-51$

Voas D and Crockett A 2005 Religion in Britain: neither believing nor belonging Sociology 39 $11-28$

Yuval-Davis N 2006 Belonging and the politics of belonging Patterns of Prejudice 40 197-214 